\title{
Investigation of color values of inkjet and laserjet prints on recycled papers
}

\begin{abstract}
The aim of this study is to compare laserjet printing and inkjet printing properties on recycled papers. In the study, we recycled reference papers prepared in accordance with the INGEDE 11p standard. After recycling the papers, we produced test papers in the laboratory environment and examined the physical and optical properties of the obtained papers. We applied calendering process at $100^{\circ} \mathrm{C}$ temperature and 20 bar pressure on the obtained test papers. After this process, we printed trigromy color measurement scales with inkjet and laserjet printers on the test papers obtaine Finally, using the spectrophotometer, we determined the printing properties of both print types.

When we examined the results, we determined that in most of the printability parameters, laserjet had a superior performance and was a more usable printing system. For example, while the inkjet cyan density value is 0.94 , the laserjet is 1.05 . While $M+Y$ trapping value was 28.23 in inkjet, it was 92.20 in laserjet. For example, we found the Gloss value as 2.53 in inkjet and 4.23 in laserjet. While inkjet cyan print chroma value is 44.03, it is 48.09 in laserjet. In addition, we determined that laserjet printing reached a wider area as a color gamut.

Based on the color measurement results of both printing types, we have determined that the printability of recycled papers is reasonable. We have determined with experimental results that laserjet printing produces better quality prints in a short time, especially in the office environment.
\end{abstract}

\author{
Ufuk Yilmaz ${ }^{1}$ \\ Ahmet Tutuş ${ }^{1}$ \\ Sinan Sönmez ${ }^{2}$ \\ ${ }^{1}$ Kahramanmaraş Sütçü Imam \\ University Forest Industry \\ Engineering \\ ${ }^{2}$ Marmara University, Applied \\ Sciences/Department of Printing \\ Technologies
}

\author{
Corresponding author: \\ ufuk Yilmaz \\ e-mail:kufu27@hotmail.com
}

First received: 27.2.2021. Accepted: 24.5.2021.

\section{KEY WORDS}

Ingede, recycling, inkjet printing, laserjet printing, cmyk

\section{Introduction}

In recent years, forest resources have decreased and demand for paper has increased. To meet these demands, the use of waste papers in pulp with the leadership of Japan and Western Europe has gained great importance. According to European Paper Recycling Council (2017), 72 \% of the paper consumed in Europe was recycled. This rate is $71.9 \%$ in 2015.Compared to 2015 , the collection of waste paper for recycling increased by $0.9 \%$ and reached 59.5 million tons. The number of countries that recycled below 60\% in 2016 decreased to 9. Currently, 17 countries recycle over 70\%. On average, paper fibers are recycled 3.6 times in Europe. According to Environmental Paper Network (2018) this rate is approximately 2.4 times higher than the world average. Again according to to European Paper Recycling Council (2017), the European Union is the region with the highest rate of paper recycling worldwide. While the world average is 58.6 percent with 2016 data, this rate is 72 in the European Union. In addition to the many advantages of recycling, the amount of chemi- 
cals, energy and water spent on recycling waste paper to pulp is much less compared to the pulp production from wood (Çiçekler \& Tutuş, 2019). Considering these data, it is possible to see that waste paper recycling is becoming more important every year. It should be noted, however, that unless we can recycle waste papers at the maximum level, we will not be fully successful. Although waste papers are a good alternative to raw materials, fiber sizes decrease after recycling. Due to the fiber length decrease, the resistance properties of the paper also decrease. As is known, the resistance properties of the paper are important factors affecting the print quality.

Paper recycling is directly connected to the printing industry. A generally preferred method for removing detached particles from the pulp is flotation (Tut$a k, 2015)$. To recycle paper, deinking has to be performed to improve the final color and overall quality of the recycled paper. Among the various de-inking methods, chemicals such as peroxides, caustic soda, and surfactants are commonly used (Mauchaufé et al., 2019). Deinking agents often include fatty acids, nonionic surfactants, or mixtures of both species, but these materials can be modified with different chemicals to achieve better results (Tutak, 2015).

The aim of this study is to compare laserjet printing and inkjet printing properties on recycled papers. The obvious advantage of laserjet printing over inkjet printing is its color gamut value, printing color value, printing gloss value, etc. (Jurič et al., 2013). A study similar to this study was carried out in the article titled Optical paper properties and their effects on color reproduction and perceived print quality. In this mentioned study, Jurič et al. (2013) used ten different types of uncoated and coated papers. It carried out a visual evaluation of the printed samples to correlate the effect of the optical properties of the paper with the printing quality under different light sources. As a result, it was determined that, unlike opacity, the whiteness and brightness of the paper were related to the print quality.

\section{Digital printing systems}

Digitalization, experienced in almost every sector on a global scale, has also affected the printing industry. With its advantages and new opportunities, it has reached the power to guide the sector. Digital printing has evolved rapidly over time and has ceased to be a replacement for traditional printing systems and has become an important part of the industry with its innovative and inspiring features (Tuncel, 2019). In recent years, many digital printing machines have been used in the printing industry. Digital printing machines have many possibilities that traditional printing systems cannot. The most important feature that makes digital printing stand out compared to other printing systems is that low-circulation jobs can be printed at a low cost.
Apart from that, digital printing systems can produce variable data as well as many features such as easy updating, printing, and distribution (Romano, 2000).

\section{Laserjet printing}

The laser printer uses a large memory to print the whole page at once. The digital page view created in the memory of the printer is transferred to the drum with the help of a laser gun. Toner sticks to the parts of the drum magnetized by the laser beam. In this way, the desired characters and graphics are formed on the paper touching the drum.

Toner: It is a component consisting of dry and very small particles called "toner", the main coloring material in copiers and laserjet printers. Depending on the production technology, the diameter of the toner grain varies between 5-10 $\mu \mathrm{m}$. Toner is powder dyes made of carbon element. They are produced in black, red, blue and yellow colors. Toner particles, in their simplest form, contain $50 \%$ iron oxide and $50 \%$ plastic. Iron oxide allows the toner to be charged electro statically easily. On the other hand, plastic material dissolves toner particles. According to the production technology of the toner particle, there are adhesives/adhesives resin/ latex, lubricant, easy dispersion counter wax and surface chemicals, and pigments (Karademir et al., 2013). The structure of the toner particle is given in Figure 1 below.
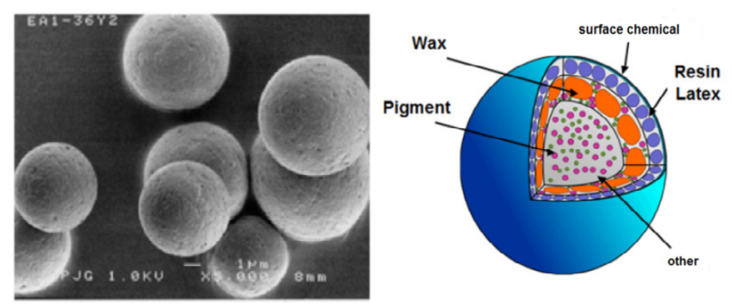

" Figure 1: The structure of the toner particle (Karademir et al., 2013)

\section{Inkjet Printing}

Inkjet printing systems are very new and developed towards the end of the 1980s for office automation applications. Requires a fundamentally different process unlike traditional methods (Karasu et al., 2019). The Inkjet printing system is applied in two ways. One is Continous Inkjet and the other is Drop-on-Demand. In Continous, ink droplets flow through the print head, while ink droplets of certain diameters are created by the applied charge process. These droplets are sent to the areas where printing is desired on paper with the charging process. In areas where printing is not required, the ink is collected in droplet holder (droplet capture) and sent back to the ink tank via a high pressure pump. Today's technology prints at 600 dpi (Hoffman, 2005). In Drop-on-Demand, ink is sprayed on paper with the help of heat. A small 
heater (Heating element) is used, which suddenly heats the ink, located inside the spray mouth. With increased heat, part of the ink evaporates, and this gas bubble pushes the remaining ink forward, thus towards the paper. This is done several thousand times per second.

These types of printers print extremely small ink droplets on the paper at high speed. These droplets are usually 50 to 60 microns in diameter (a human hair is 70 microns in diameter). Structures erupting them are lined up to store $1440 \times 720$ dots per inch resolution. Below is a schematic representation of the inkjet on-demand printer in Figure 2.

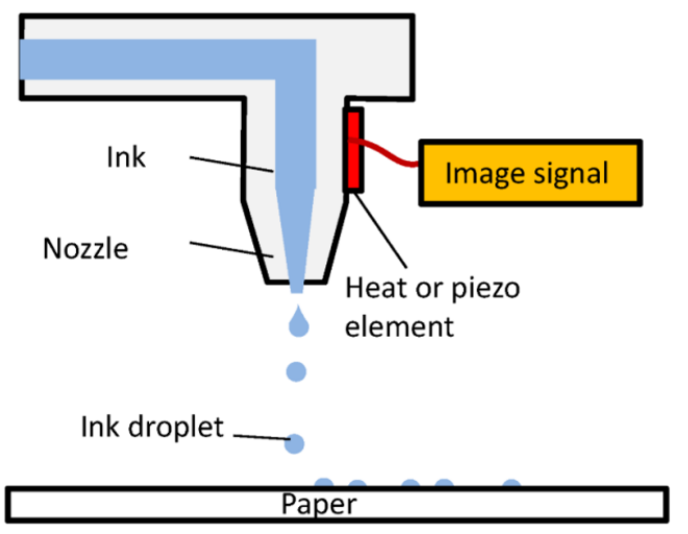

» Figure 2: Inkjet system (Lau \& Shrestha, 2017)

Inkjet water-based inks: Inkjet inks are the most important component in inkjet printing. The formulation and chemistry of inks determine the printing quality as well as jetting characteristics (Tawiah, Ebenezer \& Asinyo, 2016). They are inks in which the main carrier is water, the coloring agent is pigment or paint. The color fades quickly, the pigment is more resistant to fading. Water-based inks are inks that are not suitable for non-absorbent surfaces (Uğur, 2018).

\section{Material and Methods}

\section{Material}

In this study, standard base papers were used for recycling. All chemicals used for recycling are sourced from KSU forest industry engineering laboratories in Kahramanmaraş, Turkey. The optical properties of the base paper are given in Table 1 below.

\section{Methods}

Reference papers were torn into $2 \times 2 \mathrm{~cm}$ pieces by hand. Then, these torn papers were pulped in a Hobart type pulping device (Hobart/Germany) according to the $11 p$ standard by the following conditions.

$\begin{array}{cccc}\text { Pulping Conditions Level } & \text { Concentration (\%) } & \text { Time (Min.) } \\ \text { Prewetting } & - & 10 & 10 \\ \text { Pulping } & 1-2 & 10 & 22\end{array}$

The pulping chemicals included: sodium hydroxide $(0.6 \%)$, sodium silicate $(1.8 \%)$, hydrogen peroxide $(0.7 \%)$, and oleic acid $(0.8 \%)$ for standard INGEDE method 11p (Çiçekler \& Tutuş, 2019). The purity of the chemicals used are, sodium hydroxide (purity, \%98), hydrogen peroxide (purity, \%35), sodium silicate (purity, \%98), oleic acid (purity, \%98).

The pulp, that pulping process was completed, was transferred to the flotation unit and floated at $1 \%$ concentration according to the $11 \mathrm{p}$ standard for 30 minutes. The pulp the obtained was subjected to a two-stage bleaching process. In the first stage, 4\% FAS (formamidine sulfinic acid), and in the second stage, hydrogen peroxide bleaching was applied. Then, test papers were produced from this pulp and their optical-physical properties were determined. The calendering process was applied to the obtained test papers at $100{ }^{\circ} \mathrm{C}$ and 20 bar pressure. The produced papers were subjected to physical and optical tests by adhering to the standards after conditioning for 48 hours in an air conditioning room with a room temperature of $25 \pm 1$ and a relative humidity of $55 \pm 1 \%$. The papers obtained after this process were printed with Epson EcoTank L3060 (Epson, Japan) inkjet (water-based ink) and Canon LBP613Cdw laserjet (Canon, Japan) (toner) printers. The ink film parameters of the prints were measured with the X-Rite eXact ${ }^{\mathrm{TM}}$ spectrophotometer. In the print quality results, it was tried to reach ISO 12467-2 (International Organization for Standardization, 2013) values. The measured results were repeated 3 times and averaged. Below are the color measurement scales printed on recycled paper in Figure 3.

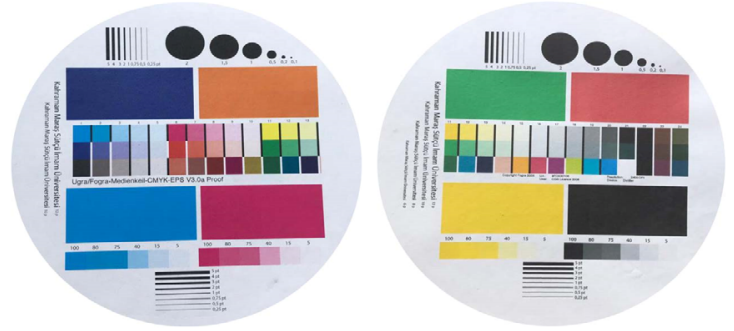

» Figure 3: Color measurement scales

Table 1

The optical properties of the base paper

\begin{tabular}{c|c|c|c|c|c|c|c}
\hline Whiteness (\% ISO) & Brightness (\% ISO) & Yellowness (E313) & CIE Whiteness & L & a & b & Opacity \\
\hline 80.12 & 98.47 & -27.66 & 145.85 & 91.74 & 3.80 & -14.29 & 92.90 \\
\hline
\end{tabular}




\section{Results}

\section{Physical and optical properties of recycled papers}

The physical properties of the laboratory test paper produced as standard after flotation, bleaching, and calendering processes are given in Table 2 .

According to TS 11610: 2017 standard, the minimum values of the physical properties that should be on $80 \mathrm{~g}$ writing papers are as follows (Çiçekler \& Tutuş, 2019);

- Breaking length (transverse and longitudinal): 2000-4000 meter

- Burst index: $1.3\left(\mathrm{kPa} \mathrm{m}^{2} / \mathrm{g}\right)$

- Bulkiness: $1.2-1.5\left(\mathrm{~cm}^{3} / \mathrm{g}\right)$

- Intensty: 0.6-0.8 $\left(\mathrm{g} / \mathrm{cm}^{3}\right)$

When Table 2 is examined, it is seen that the physical properties of the produced test paper after recycling are within the standards. The optical properties of recycled test paper are given in Table 3 below.

The physical and optical properties of a paper are important factors affecting the print quality. For the printing (inkjet, laserjet) conditions to be equal, papers with the same features were produced.

\section{Print properties of recycled paper}

Print quality parameters of recycled papers are examined in detail below.

\section{CMYK print density and dot gain}

Print density is the amount of ink remaining on the print layer. (Gong, Fleming \& Sönmez, 2010). Print density, which is an important factor to be considered for printed products, affects the perceived saturation of a color and is a practical way of evaluating the depth of the tone in the print (Hu et al., 2017). Dot gain, or tonal value increase, is a phenomenon in printing which causes printed material to look darker than intended. It is caused by halftone dots growing in area between the original printing film and the final printed result. In practice, this means that an image that has not been adjusted to account for dot gain will appear too dark when it is printed. Dot gain calculations are often an important part of a CMYK color model. The density and dot gain values of the highgrade paper pulp ISO 12647-2, inkjet and laserjet prints made on recycled papers are given in Table 4 below.

When Table 4 is examined, it is seen that the inkjet and laserjet prints have close to CMYK density values. Nevertheless, it was determined that the density values of laserjet printing in all colors were higher. In both types of printing, it was determined that black color density values were highest and cyan color density values

\section{Table 2}

Physical properties of recycled paper

\begin{tabular}{|c|c|c|c|c|c|c|}
\hline$\underset{\left(\mathrm{g} / \mathrm{m}^{2}\right)}{\text { Grammage }}$ & $\begin{array}{c}\text { Breaking } \\
\text { lenght }(\mathrm{m})\end{array}$ & 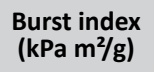 & $\begin{array}{l}\text { Tear index } \\
\left(\mathrm{mN} \cdot \mathrm{m}^{2} \cdot \mathrm{g}\right)\end{array}$ & $\begin{array}{l}\text { Air permeability } \\
\qquad\left(\mathrm{m}^{3} / \mathrm{dk}\right)\end{array}$ & $\begin{array}{l}\text { Intensity } \\
\left(\mathrm{g} / \mathrm{cm}^{3}\right)\end{array}$ & $\begin{array}{c}\text { Bulkiness } \\
\left(\mathrm{cm}^{3} / \mathrm{g}\right)\end{array}$ \\
\hline 88 & 5466 & 3.39 & 6.37 & 242.91 & 0.62 & 1.6 \\
\hline
\end{tabular}

Table 3

Optical properties of recycled paper

\begin{tabular}{c|c|c|c|c|c|c|c|c}
\hline $\begin{array}{c}\text { Whiteness } \\
\text { (\% ISO) }\end{array}$ & $\begin{array}{c}\text { Brightness } \\
\text { (\% ISO) }\end{array}$ & $\begin{array}{c}\text { Yellowness } \\
\text { (E313) }\end{array}$ & CIE Whiteness & L & a & b & Opacity & $\begin{array}{c}\text { ERIC } \\
\text { (PPM) }\end{array}$ \\
\hline 73.4 & 86.01 & -20.11 & 124.99 & 88.61 & 3.67 & 10.86 & 97.55 & 251.92 \\
\hline
\end{tabular}

\section{Table 4}

Density values for inkjet and laserjet prints

\begin{tabular}{c|c|c|c|c|c|c|c|c|c}
\hline & \multicolumn{3}{|c|}{ Print density (\%) } & \multicolumn{6}{c}{ Dot gain (\%) } \\
\cline { 2 - 10 } & Inkjet & Laserjet & ISO 12647-2 & $\begin{array}{c}\text { Inkjet } \\
\mathbf{8 0} \\
(\%)\end{array}$ & $\begin{array}{c}\text { Inkjet } \\
\mathbf{4 0} \\
(\%)\end{array}$ & $\begin{array}{c}\text { Laserjet } \\
\mathbf{8 0} \\
(\%)\end{array}$ & $\begin{array}{c}\text { Laserjet } \\
\mathbf{4 0} \\
(\%)\end{array}$ & $\begin{array}{c}\text { ISO 12647-2 } \\
\mathbf{8 0} \\
(\%)\end{array}$ & $\begin{array}{c}\text { ISO 12647-2 } \\
\mathbf{4 0} \\
(\%)\end{array}$ \\
\hline Cyan & 0.94 & 1.05 & 1.55 & 19.43 & 18.66 & 18.8 & 19.9 & 12 & 19 \\
\hline Magenta & 1.02 & 1.08 & 1.20 & 8.23 & 7.13 & 9.43 & 11.06 & 12 & 19 \\
\hline Yellow & 1.09 & 1.14 & 1.15 & 19.4 & 16.6 & 18.43 & 18.63 & 12 & 19 \\
\hline Black & 1.30 & 1.41 & 1.20 & 7.9 & 1.47 & 8.73 & 6.7 & 14 & 22 \\
\hline
\end{tabular}


were lowest. When we compare the density values with the following standard values (ISO 12647-2), it is seen that CMY colors are below the standards in both printing types. When we examine the dot gain values, the dot gain was higher in all of the CMYK colors of laserjet printing in the 40 screen area. It is seen that the dot gain in the 80's area is more in cyan and yellow inkjet printing. For printing quality, it is recommended to use a lower screen frequency on matte surface papers. Therefore, it is considered to be more accurate to consider the dot gain measurements made in the 40 screen area. It was observed that the dot gain values measured in the 80 screen area in inkjet printing were outside the standard values. In laserjet printing, the dot gain values of the cyan and yellow colors in the 80 screen area were outside the standards.

\section{CMYK trapping and print contrast}

Trapping is the acceptance of a second color overlapping a color in print. Print contrast can be defined as the difference between the darkest and brightest parts of the obtained image in print. For high print quality, it is desirable to have high print contrast. The properties of the paper are the most important factors affecting the printing contrast (Sönmez, 2011). The trapping and print contrast values of inkjet and laserjet prints made on recycled papers are given in Table 5 below.

\section{Table 5}

Trapping and print contrast values of inkjet and laserjet prints

\begin{tabular}{c|c|c|c|c|c}
\hline \multicolumn{2}{c|}{} & \multicolumn{3}{c}{ Print contrast (\%) } \\
\cline { 3 - 6 } \multicolumn{2}{c|}{} & Color & Inkjet & Laserjet \\
\hline Color & Inkjet & Laserjet & Cyan & 11.03 & 9.63 \\
\hline $\mathrm{M}+\mathrm{Y}$ & 28.23 & 92.2 & Magenta & 38.60 & 38.17 \\
\hline $\mathrm{C}+\mathrm{Y}$ & 76.90 & 98.17 & Yellow & 12.90 & 13.33 \\
\hline $\mathrm{C}+\mathrm{M}$ & 55.37 & 94.07 & Black & 49.03 & 47.07 \\
\hline
\end{tabular}

When Table 5 is examined, it is determined that the trapping values of laserjet printing give much better results on recycled papers. In inkjet printing, magenta + yellow colors are determined as the lowest acceptance rate, and cyan + yellow colors are determined as the highest rate in laserjet printing. Trapping values the $70-75 \%$ range is accepted as standard. This value is requested to be high. Less than 65\% is considered insufficient (YIImaz, 2016). According to standard values, the best result in trapping values is the $\mathrm{C}+\mathrm{Y}$ colors of laserjet printing. The worst result is the $\mathrm{M}+\mathrm{Y}$ colors of inkjet printing. When the print contrast values and the surface properties of the paper are examined, it is seen that the results obtained are ideal. Although there is not a big difference, it is seen that inkjet printing has superior performance, even if it is very small, in terms of print contrast to laserjet printing. In both printing types, the printing contrast values of cyan and yellow color were below the standard values. It has been observed that inkjet printing values are higher in cmk colors and laserjet printing has a superior performance in yellow. Magenta and black colors are seen to be in standard and desired values (Yllmaz, 2018).

\section{CMYK gloss and print chroma}

Gloss measurements were made with a BYK Gardner GmbH gloss meter according to ISO 2813:2014 (International Organization for Standardization, 2014), 60 geometry (Özcan et al., 2019). Chroma means color saturation and can be measured by the color intensity channel. Chroma values that are decisive for print quality are desired to be high (Sönmez, 2011). The gloss and print chroma values of inkjet and laserjet prints made on recycled papers are given in Table 6 below.

\section{Table 6}

Chroma and gloss values of inkjet and laserjet prints

\begin{tabular}{c|c|c|c|c|c}
\hline \multirow{2}{*}{} & \multicolumn{3}{|c|}{ Gloss } & \multicolumn{2}{c}{ Print chroma } \\
\cline { 2 - 6 } & Paper & Inkjet & Laserjet & Inkjet & Laserjet \\
\hline Cyan & 4.17 & 2.53 & 4.23 & 44.03 & 48.09 \\
\hline Magenta & 4.17 & 2.37 & 4.63 & 53.40 & 56.09 \\
\hline Yellow & 4.17 & 3.73 & 6.10 & 67.45 & 72.28 \\
\hline Black & 4.17 & 1.47 & 4.03 & 2.90 & 1.81 \\
\hline
\end{tabular}

When Table 6 is examined, it can be seen that the gloss values of laserjet printing perform better. The gloss of the laserjet print in black was found to be almost 3 times the gloss of the inkjet print. In Magenta color, this ratio was found almost 2 times. It is seen that the highest value is yellow in laserjet printing, and the lowest value is black in inkjet printing. When the chroma values are analyzed, we can see that laserjet printing produces better results in recycled papers. In black, it is seen that inkjet printing has a higher value than laser jet. It is seen that laserjet printing has an obvious advantage in CMY colors.

\section{CIE L*, CIE a* and CIE $b^{*}$ values and color gamut}

$\mathrm{CIE}$ is designed many colour universe models over time. Although these different in technological development processes, the basis is colour, saturation and brightness properties. The main purpose of CIE is to create a repeatable system of colour communication standards for material manufacturers such as paint and ink. Providing a universal template for colour matching is the most important function of these standards (Nussbaum, 2010). As a result, simple values can be used to describe the adjectives red/green and yellow/blue. This color pattern is often used as the basis for color vision (Mokrzycki \& Tatol, 2009). In CIE L* $a^{*} b^{*}, L^{*}$ shows lightness, a red/ green, $b^{*}$ yellow/blue (Köse \& Şahinbaşkan, 2008). 
$L^{*} a^{*}$ and $b^{*}$ values measured for color gamut and printing chroma values are given in Table 7 below.

\section{Table 7}

$L^{*}, a^{*}$ and $b^{*}$ values of inkjet and laserjet prints

\begin{tabular}{c|c|c|c|c|c|c}
\hline & \multicolumn{3}{|c|}{ Inkjet } & \multicolumn{3}{c}{ Laserjet } \\
\hline & L* & a* & b* & L* & $\mathbf{a}^{*}$ & b* $^{*}$ \\
\hline C & 57.51 & -17.74 & -40.25 & 55.16 & -21.16 & -43.13 \\
\hline M & 53.1 & 53.27 & 3.49 & 51.14 & 55.90 & 4.31 \\
\hline Y & 81.63 & 3.41 & 67.37 & 83.53 & -4.68 & 72.12 \\
\hline K & 31.90 & 2.82 & 0.64 & 26.32 & 1.76 & 0.36 \\
\hline R & 56.18 & 15.80 & 20.20 & 48.64 & 53.79 & 35.32 \\
\hline G & 56.59 & -11.90 & 20.34 & 47.10 & -48.57 & 17.06 \\
\hline B & 41.64 & 1.71 & -31.30 & 30.98 & 8.80 & -36.64 \\
\hline
\end{tabular}

As it is known, color gamut and print chroma values are measured by means of $L^{*} a^{*} b *$ values. When we examined the $L^{*}$ values of both prints, it was seen that the inkjet printing values were higher in $\mathrm{c}, \mathrm{m}$ and $\mathrm{k}$ colors. It has been determined that the yellow color has a higher $L^{*}$ value in laserjet printing. When we examine the $a^{*}$ values, it was determined that the $\mathrm{C}, \mathrm{Y}$ and $\mathrm{K}$ colors are higher in inkjet printing. When we examine the $b^{*}$ values, it was determined that the inkjet printing value in cyan and black color is high, and the laserjet printing value is high in magenta and yellow color. It was determined that the laserjet printing value was higher in magenta color. When we look at the color gamut, it has been observed that laserjet printing reaches a wider color spectrum.

Gamut refers to the RGB colors, which are the computer format of the colors to be printed. It also express to all the shades of CMYK colors, which are the format on the print material, in the gamut. While creating the color gamut, the RGB color space must be converted to the CMYK color space. It can be defined as follows; On the highest level, the aim of color gamut "is to ensure a good correspondence of overall color appearance between the original and the reproduction by compensating for the mismatch in the size, shape and location between the original and reproduction gamuts (Morovic \& Luo, 2001). In addition, the color gamut can be defined as the range of colors that a particular device can produce or save. If the Gamut value is high, the color gamut obtained in printing will be so wide (YIlmaz, 2018; Chen, Berns \& Taplin, 2004). In order to create a color gamut, $L * a * b *$ values of both CMYK and RGB colors were measured with X-Rite eXact ${ }^{\mathrm{TM}}$ Spectrophotometer (D50 illuminant, $2^{\circ}$ observer, $0 \% 45^{\circ}$ geometry, black backing). In the second stage, a pivot table was created in the excel program. The color gamut was obtained by entering the measured lab values into the created pivotable. When we examine Figure 4, we can see that the color gamut of laserjet printing reaches a much higher area than the color gamut of inkjet printing. The wider the color gamut, the greater the color processing and image quality. In this case, it is seen that laserjet has a much wider color diversity than inkjet.

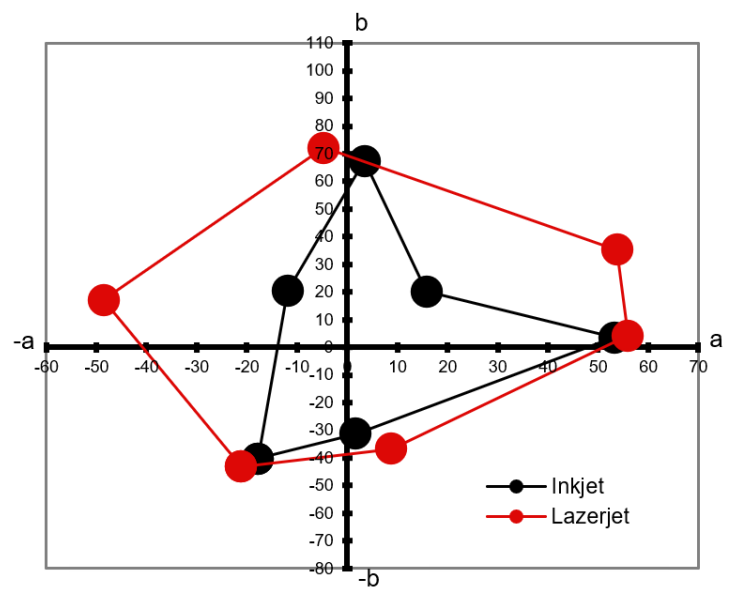

» Figure 4: Color gamut of inkjet and laserjet prints

\section{Examination of microscope images}

Binocular Light Microscope with 2000x Magnification microscope was used for these images. These images were made at coaxial coarse and fine focus settings. Coarse adjustment working distance: $36 \mathrm{~mm}$, fine adjustment working distance: $0.002 \mathrm{~mm}$.

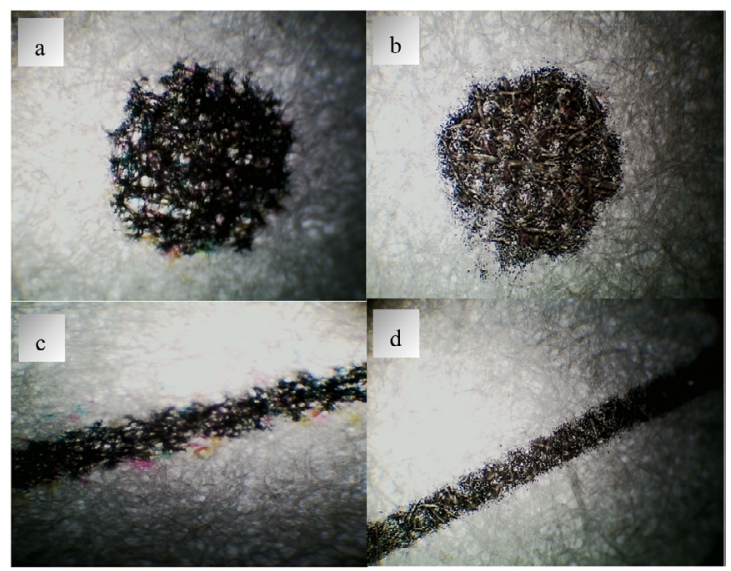

» Figure 5: $0.1 p t$. dot (4x), (a; inkjet, b; laserjet), 0.5 pt. line $(4 x)$ (c; inkjet, $d$; laserjet)

When the Figure 5 magnified 4 times $(4 x)$ is carefully examined, it is seen that a clearer print is obtained with Laserjet printing from both 0.1 point dot and 0.5 point line printing.

\section{Conclusions}

It is known by everyone that the recycling of paper is very important both in terms of cost and conservation of natural resources. In addition, secondary fibers obtained from recycled papers are considered not to have the print quality as much as paper made from primary fibers. In this study, inkjet and laserjet print- 
ing properties of recycled papers were determined. According to the study data; It has been observed that there is a certain difference in inkjet and laserjet printing density of recycled papers. It has been observed that dot gain values of laserjet printing are higher than inkjet printing. When the trapping values are examined, the obvious superiority of laser printing over inkjet printing is noted. Although there is not a huge difference in value in print contrast, it is seen that the inkjet performs better than laserjet printing. When we look at the gloss values of recycled papers, laserjet printing has been observed to give better results. When the print chroma values were examined, it was determined that the laserjet printing was higher in the CMY colors and the inkjet printing was higher in the black color.

As a result, it has been determined that both printing systems dominate each other in different printing parameters. Considering all the data, it has been seen that inkjet and laserjet prints have appropriate results in terms of print quality in the recycled paper in general.

\section{Acknowledgements}

The authors thank Kahramanmaraş Sütçü Imam University Scientific Research Projects Unit for supporting this study with the project number 2019 / 1-13D.

\section{References}

Chen, Y., Berns, R. S. \& Taplin, L. A. (2004) Extending Printing Color Gamut by Optimizing the Spectral Reflectance of Inks. In: CIC 2004: The Twelfth Color Imaging Conference: Color Science and Engineering, CIC 2004, 9 November 2004, Scottsdale, Arizona. Springfield, IS\&T- The Society for Imaging Science and Technology.

Çiçekler, M. \& Tutuş, A. (2019) Atık GazeteKağıtlarının Geri Dönüşümü Üzerine Bir Araştırma. In: AGRIFOR: International Congress on Agriculture and Forestry Research, AGRIFOR, 8-10 April 2019, Marmaris, Turkey. Marmaris, AGRIFOR. pp. 125-135.

Enviromental Paper Network (2018) The State Of The Global Paper Industry. Enviromental Paper Network.

European Paper Recycling Council (2017) Monitoring Report 2017 European Declaration on Paper Recycling 2016-2020. Brussels, European Paper Recycling Council.

Gong, R., Fleming, P. D. \& Sönmez, S. (2010) Application Of Nano Pigments In Inkjet Paper Coating. In: NIP26: 26th International Conference On Digital Printing Techologies, NIP26, 19-23 September 2010, Austin, Texas. Springfield, IS\&T- The Society for Imaging Science and Technology. pp. 507-511.

Hoffman, M. (2005) Digital Printing Technology and Printing. Poing, Oce Printing Systems GmbH.

Hu, G., Fu, S., Chu, F. \& Lin, M. (2017) Relationship between Paper Whiteness and Color Reproduction in Inkjet Printing. Bioresources. 12 (3), 4854-4866, Available from: doi: 10.15376/biores.12.3.4854-4866

International Organization for Standardization (2014) ISO 2813:2014. Paints and varnishes - Determination of gloss value at 20 degrees, 60 degrees and 85 degrees. Geneva, International Organization for Standardization.

International Organization for Standardization. (2013) ISO 12647. Graphic Technology, Process Control For The Production Of Half-Tone Colour Separations, Proof And Production Prints. Geneva, International Organization for Standardization.

Jurič, I., Karlovits, I., Tomić, I. \& Novaković, D. (2013) Optical paper properties and their influence on colour reproduction and perceived print quality. Nordic Pulp and Paper Research Journal. 28 (2), 264-273. Available from: doi: 10.3183/npprj-2013-28-02-p264-273

Karademir, A., Karahan, S., Imamoglu, S., Ertas, M., Aygan, A., Aydemir, C. \& Pesman, E. (2013) Use of enzyme and ultrasonic energy in paper recycling. Journal of History Culture and Art Research. 1 (4), 280-297. Available from: doi: 10.7596/taksad.v1i4.127

Karasu, B., Karabulut, D., Biçer, A., Varol, U. C. \& Oytaç, Z. E. (2019) Seramik Sektöründe İnkjet Dekorasyon Uygulamaları. El-Cezerî Journal of Science and Engineering. 6 (3), 691-711. Available from: doi: 10.31202/ ecjse. 572176

Köse, E. \& Şahinbaşkan, T. (2008) Renk Yönetiminde Kullanılan Standart ICC Profillerinin Türkiye'de Oluşturulmuş Bazı Profillerile Karşılaştrııması. Politeknik Dergisi. 11 (4), 365-371.

Lau, G. K. \& Shrestha, M. (2017) Inkjet Printing of Micro-Electro-Mechanical Systems (MEMS). Micromachines. 8 (6), 194. Available from: doi: 10.3390/ mi8060194

Mauchaufé, R., Lee, S. J., Han, I., Kim, S. H. \& Moon, S.Y. (2019) Improved de-inking of inkjet-printed paper using environmentally friendly atmospheric pressure low temperature plasma for paper recycling. Scoemtofoc Reports. 9. Available from: doi: 10.1038/s41598019-50495-4

Mokrzycki, W. \& Tatol, M. (2009) Perceptual difference in $L^{*} a^{*} b^{*}$ color space as the base for object colour identfication. In: 1 'st International Conference on Image Processing \& Communications, August. Available from: doi: 10.13140/2.1.1160.2241

Morovic, J. \& Luo, M. R. (2001) The Fundamentals of Gamut Mapping: A Survey. Journal of Imaging Science and Technology. 45 (3), 283-290.

Nussbaum, P. (2010) Colour Measurement and Print Quality Assessment in a Colour Managed Printing Workflow. PhD thesis. Gjovik University College.

Ozcan, A., Kandirmaz, E. A., Hayta, P. \& Mutlu, B. (2019) Examination Of The Effect Of Melamine As A Filler In Paper Coatings On Print Quality. Cellulose Chemistry And Technology. 53 (3-4), 307-313. Available from: doi: 10.35812/CelluloseChemTechnol.2019.53.30 
Romano, F. J. (2000) Digital Printing. San Diego, Windsor Professional Information.

Sönmez, S. (2011) Interactive Effects Of Copolymers And Nano-Sized Pigments On Coated Recycled Paperboards in Flexographic Print Applications. Asian Journal Of Chemistry. 23 (6), 2609-2613.

Tawiah, B., Ebenezer, K. \& Asinyo, B. K. (2016) The Chemistry Of Inkjet Inks For Digital Textile Printing. BEST: International Journal of Management, Information Technology and Engineering. 4 (5), 61-78.

Tuncel, O. (2019) Dijital Çağda Baskı Teknolojileri. Sanatve Tasarım journal. (23), 361-377.

Tutak, D. (2015) Modified Deinking Of Digitally Printed Paper With Water Based Inkjet Ink. Cellulose Chemistry And Technology. 51 (5-6), 483-488.

Uğur, E. (2018) İnkjet (Mürekkep Püskürtmeli) Dijital Baskı Teknolojilerin Çalışma Sisteminin Tanımlaması ve Kullanım Alanlarının Kategorizasyonu. Journal of Social, Humanities And Administrative Sciences. 4 (10), 75-85. Available from: doi: 10.31589/JOSHAS.40

Yılmaz, U. (2016) Bazi Kağitlarin Fiziksel Özelliklerinin Ofset Baski Kalitesine Etkisinin Incelenmesi. MSc thesis. Kahramanmaras Sutcu Imam University.

Yılmaz, U. (2018) Investigation of The Effect on Print Contrast of Optical Properties of Paper in Offset Printing. In: 6th International Printing Techologies Symposium, 1-3 November 2018, Istanbul, Turkey. Istanbul, Istanbul University. pp 1165-1171.

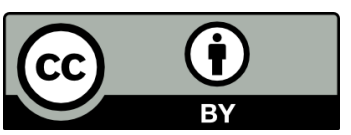

(C) 2021 Authors. Published by the University of Novi Sad, Faculty of Technical Sciences, Department of Graphic Engineering and Design. This article is an open access article distributed under the terms and conditions of the Creative Commons Attribution license 3.0 Serbia (http://creativecommons.org/licenses/by/3.0/rs/). 